\title{
Groundcover Management System and Nutrient Source Impacts on Soil Quality Indicators in an Organically Managed Apple (Malus $\times$ domestica Borkh.) Orchard in the Ozark Highlands
}

\author{
Neal Mays and Curt Richard Rom ${ }^{1}$ \\ Department of Horticulture, University of Arkansas, Plant Sciences Building, \\ Room 316, Fayetteville, AR 72701
}

Kristofor R. Brye and Mary C. Savin Department of Crop, Soil, and Environmental Sciences, University of Arkansas, PTSC 115, Fayetteville, AR 72701

\author{
M. Elena Garcia \\ Department of Horticulture, University of Arkansas, Plant Sciences Building, \\ Room 316, Fayetteville, AR 72701
}

Additional index words. soil quality, groundcover management system, organic production

Abstract. The highly weathered, mineral, and often eroded and acidic soils of the Ozark Highlands region of northwest Arkansas generally have low soil organic matter (SOM) concentrations as a result of rapid organic matter turnover rates in the warm, moist climate. Orchard management practices that can improve SOM may also improve other soil quality-related variables for sustained production, which is an explicit goal for the National Organic Program (NOP). Therefore, beginning in Mar. 2006 and continuing for seven seasons, annual applications of municipal green compost, shredded office paper, wood chips, and mow-blow grass mulch groundcover management systems (GMS) in combination with composted poultry litter, commercial organic fertilizer, or a nonfertilized control as a nutrient source were implemented to evaluate their ability to alter near-surface soil quality in a newly established, organically managed apple orchard in the Ozark Highlands region of northwest Arkansas. The SOM concentration in the top $10 \mathrm{~cm}$ averaged $1.5 \%$ across all treatments at orchard establishment in 2006, but by 2012, SOM concentration had increased in all GMS and more than doubled to $5.6 \%$ under green compost. Similarly, soil bulk density in the top $6 \mathrm{~cm}$, which averaged $1.34 \mathrm{~g} \cdot \mathrm{cm}^{-3}$ among treatment combinations in 2006, decreased in all GMS by 2012. Either green compost or shredded paper had the largest concentration of total water-stable aggregates across all aggregate size classes in the top $7.5 \mathrm{~cm}$, whereas no differences among GMS were observed in the 7.5- to $15-\mathrm{cm}$ soil depth. Green compost applied alone or in combination with commercial fertilizer had the largest estimated plant-available water $(17.9 \% \mathrm{v} / \mathrm{v})$ among all treatment combinations. Many soil quality-related variables measured in the various organic GMS had numerically greater values compared with an adjacent conventionally managed orchard on the same soils. Implementation of these GMS appears to provide apple producers in the Ozark Highlands and similar regions a tangible means of meeting NOP requirements for improving soil quality concurrent with production of certified organic crops. The findings also have implications for conventionally managed orchards, which have maintaining or improving soil quality as a management goal.

The U.S. Department of Agriculture (USDA) NOP soil fertility and crop nutrient management practice standard $(\$ 205.203)$

\footnotetext{
Received for publication 26 Mar. 2014. Accepted for publication 25 June 2014.

This paper was also presented as a portion of a thesis, which partially fulfilled MS degree requirements.

${ }^{1}$ To whom reprint requests should be addressed; e-mail crom@uark.edu.
}

requires agriculture production systems 1) to "select and implement tillage and cultivation practices that maintain or improve the physical, chemical, and biological condition of soil and minimize soil erosion"; 2) to "manage crop nutrients and soil fertility through rotations, cover crops, and the application of plant and animal materials"; and 3) to "manage plant and animal materials to maintain or improve soil organic matter content in a manner that does not contribute to contamination of crops, soil, or water by plant nutrients, pathogenic organisms, heavy metals, or residues of prohibited substances" (USDA Agricultural Marketing Service, 2012). Many studies support opinions held by producers that increases in SOM enhance physical and chemical soil properties and management practices that favor the aggradation of SOM result in plant growth and productivity benefits (Kimble, 2007). Merwin et al. (1994) suggested comparisons between organic, or integrated orchard management systems, and conventional orchard management practices may reveal measurable differences in SOM levels. Qualitative characterizations of conventionally managed orchard soils reflect lower soil quality for the soil ecosystem than for organic or integrated systems (Reganold et al., 2001), whereas greater soil quality in organic and integrated systems is attributed to organic residue additions to the soil surface through the use of various GMS. Such GMS provide continuous additions of SOM to the soil and likely have a positive effect on overall soil quality in organic orchards.

The addition of SOM to mineral soil is a recognized beneficial practice from the standpoint of increasing the capacity of the soil to store plant-available water (Bhogal et al., 2009; Hudson, 1994; Jordán et al., 2010; Mulumba and Lal, 2007). Organic constituents from crop residues, manures, and composts tend to absorb water as water moves through a soil profile, thus enhancing the soil's water-holding capacity.

Likewise, applications of organic material, including applied mulches, incorporation of green manure crops, livestock manure, and compost, increase soil porosity and reduce soil bulk density (BD) and potential compaction (Celik et al., 2010; Jordán et al., 2010; Soane, 1990; Stock and Downes, 2008). Soil BD is related to other soil physical properties and has been described as an indicator of soil and environmental quality (Arshad and Coen, 1992; Doran et al., 1996; Lal and Kimble, 2001). Decreases in soil BD may be achieved as soil aggregation improves, where the beneficial aspects of well-aggregated soils include protection of SOM within the aggregate (Tisdall and Oades, 1982), increased diversity of the soil microbial community (Fliebach et al., 2006), enhanced soil, air, and water movement (Deurer et al., 2009), and a reduction of surface crusting, runoff, and soil erosion (Carter, 2002; Karlen et al., 1992; Kemper and Rosenau, 1986).

Surface crusting and erosion may be reduced or eliminated in orchards with application of non-living groundcover mulches. Mulches useful for organic apple (Malus $\times$ domestica Borkh.) production include woodchips, municipal green compost, shredded paper, and mow-blow green mulch (Rom et al., 2010). Other researchers have used hay-straw and living groundcovers, including white clover (Trifolium repens L.) and red clover (Trifolium pratense L.), all of which contribute to SOM reserves (Granatstein and Mullinix, 2008; Merwin et al., 1994, 1995, 1999; Sanchez et al., 2003) and favor formation of water-stable soil aggregates. 
An important constituent for binding aggregates into water-stable forms and supporting maintenance and growth of a healthy soil food web is carbon (C). Soil aggregates are instrumental in storing and protecting $\mathrm{C}$ mineralized from decomposed residues. Carbon in soil aggregates exists in a variety of forms, from decomposing, labile particulate organic matter bound into aggregates by fine roots and hyphae to stable, humidified plant residues occluded within small microaggregates and unavailable to the soil microbial community (Kay, 1998; Tisdall and Oades, 1982). Furthermore, polysaccharides and mucilages exuded from soil micro-organisms may also be tightly adsorbed onto mineral soil particles, thereby strengthening aggregate fracture zones and decreasing the potential for slaking (Kay, 1998).

Tisdall and Oades (1982) categorized soil aggregates as either macroaggregates (i.e., greater than $0.25 \mathrm{~mm}$ diameter) or microaggregates (i.e., less than $0.25 \mathrm{~mm}$ diameter). Macroaggregates are usually bound by plant roots and fungal hyphae and tend to decline in number as SOM declines (Jastrow and Miller, 1991; Karlen et al., 1992; Tisdall and Oades, 1982). Microaggregates are fixed by polysaccharides and organo-mineral complexes to form relatively stable structures largely unaffected by soil management practices (Six et al., 2004; Tisdall and Oades, 1982).

The porous nature of well-aggregated soils affects the rate at which water enters the soil profile (i.e., infiltration) and the extent to which water can enter a soil impacts the amount of water runoff. Greater runoff increases the erosion potential (Lado et al., 2004; Le Bissonnais, 1996; Stern et al., 1991; Wakindiki and Ben-Hur, 2002) and decreases the water that can be stored in the soil for plant growth (Merwin et al., 1994).

To reduce water droplet impact and promote the formation of stable aggregates, land management strategies that concentrate residues at the soil surface are often recommended, and greater water-stable aggregate content can improve infiltration by slowing crust formation during a rain or irrigation event (Albrecht and Sosne, 1944; Boyle et al., 1989; Freebairn et al., 1991; Lal, 1993; Le Bissonnais, 1996; Le Bissonnais and Arrouays, 1997). The arrangement of macroaggregates with respect to one another creates macropores (Deurer et al., 2009), and pore size and pore volume per volume of soil dictate the rate at which water can infiltrate into the soil (Arshad and Coen, 1992).

Studies have shown application of mulches in apple orchards increased infiltration rates (Goh et al., 2001; Granatstein and Mullinix, 2008) and soil aggregate stability (Deurer et al., 2008). Mulches provide additional benefit of permitting water infiltration into the soil and greater retention as a result of reductions in evaporation, thereby reducing irrigation requirements (Granatstein and Mullinix, 2008). After 6 years of orchard research, Merwin et al. (1994) documented decreased SOM and water infiltration in plots treated with pre-emergence herbicides and tillage as compared with those managed with living and inert mulches.

The southeastern United States has experienced increased interest in orchard establishment and fruit production, especially small-scale and organically managed farms. A considerable amount of information is available on the efficacy and suitability of using GMS systems as an orchard floor management tool in other, more northern regions of the United States, but no research exists that shows their effects on physical properties of the old, highly weathered soils of the Ozarks Highlands and similar regions. Furthermore, the impact of organic nutrient sources on organically managed orchard soils in the Ozark Highlands or south has not been documented. Therefore, the objectives of this study were 1) to evaluate the impact of groundcover management system and nutrient source on soil quality-related variables such as SOM, BD, plant-available water, water-stable aggregation, saturated hydraulic conductivity, and water infiltration in an organically managed apple orchard; and 2) to qualitatively compare soil quality in an organic apple orchard with those to an adjacent conventionally managed orchard on a highly weathered soil in the Ozark Highlands region of northwest Arkansas. It was hypothesized that use of GMS that increase SOM will also increase water-stable soil aggregation, which will lead to an overall increase in water infiltration and plant-available water. It was further hypothesized that organic nutrient sources will enhance SOM, water-stable aggregation, infiltration, and water-holding capacity and result in decreased BD.

\section{Materials and Methods}

This study was part of a long-term study examining the impacts of GMS and nutrient sources on tree development, health, and productivity and insect, disease, and competitive vegetation management in an organically managed apple orchard (Choi et al., 2009). The 0.4-ha experimental orchard was located at the University of Arkansas, Division of Agriculture System, Arkansas Agricultural Research and Extension Center in Fayetteville, AR (lat. $36^{\circ} \mathrm{N}$, long. $94^{\circ} \mathrm{W}$ ) and situated on two soil series. Two-thirds of the experimental orchard was on a Pickwick silt loam (fine-silty, mixed semiactive, thermic Paleudult) with the remainder of the area located on a Captina silt loam (fine-silty siliceous, active, mesic Typic Fragiudult; USDA, 1969). Soil survey descriptions for both soils specify low to moderate natural fertility, low SOM concentrations, low to moderate soil $\mathrm{pH}$, and moderate to high plant-available water (USDA, 1969). The Captina series has a root- and water-limiting fragipan in the subsoil. Both soils are well suited for fruit production. Similarly, both soils typify highly weathered, mineral upland soils of the Ozark Highlands (Brye et al., 2013).

The experimental organic orchard site had been in horticultural crop production for $\approx 75$ years. Before orchard establishment, the site was prepared and cultivated in 2005 (described in Mays et al., 2014). Using soil test results, soil $\mathrm{pH}$ was adjusted with agricultural lime and $5 \mathrm{t} \cdot \mathrm{ha}^{-1}$ of composted manure was applied to prepare the planting beds. In 2006, 'Enterprise'/M26 apple trees were planted with $2 \mathrm{~m}$ between trees and $4 \mathrm{~m}$ between rows to achieve an approximate tree density of 1485 trees/ha and trained to a two-wire trellis with vertical tree supports in a modified vertical axis system. Orchard management followed NOP regulations for certification. Plots were planted with triplicate trees with measurement trees in each treatment combination being the center tree and buffered from adjacent treatment effects by guard trees on either side that were managed identically to the measurement tree. Guard trees were established along the outside ends and rows of the orchard. Drive-row alleys between tree rows were perennially managed with established 'Kentucky-31' tall fescue (Festuca arundinacea Schreb.) and native herbaceous plants that were naturally present.

Beginning in Mar. 2006 and annually thereafter, four GMS treatments were applied as 1) shredded paper; 2) wood chips; 3) green compost; and 4) mow-blow and three nutrient source treatments as follows: 1) commercial fertilizer; 2) poultry litter; and 3) non-fertilized control. The GMS treatments were applied under the tree canopy in a 2-m width and approximate 4- to $10-\mathrm{cm}$ deep band extending across both sides of the tree row and extending across the entire nine-tree GMS plot. The depth of treatment varied with difference in soil surface terrain, amount of material to cover vegetation, and seasonal differences. The nutrient source treatments were applied uniformly under the tree canopy in a 2-m width band extending the entire three-tree subplot. The single sample plot was $2 \mathrm{~m}$ across row width $\times 2 \mathrm{~m}$ in-row strip. The experimental design was a randomized complete block factorial replicated six times, where each block contained all 12 of the possible treatment combinations with GMS as the main plot and nutrient source as the subplot factor.

Shredded office paper was obtained from the University of Arkansas and the wood chips, originating from primarily hardwood species, were obtained from the city of Fayetteville, AR. The green compost material, derived of urban vegetative waste (i.e., grass clippings, wood prunings, and yard waste) and composted for between 90 and 120 d, was obtained from the city of Fayetteville, $A R$, and used through the 2011 growing season. Beginning in 2012, the green compost material used was obtained from PC Turnkey, Springdale, AR, and consisted of grass clippings, leaves, and wood chips composted using an active-pile process. The mow-blow green mulch treatment, which served as an informal control, was applied to the treatment area within the tree row by rotary mower in late May and three to five times throughout the summer each year depending on drive-row vegetative growth. 
The commercial fertilizer used from the initiation of the study through the 2011 application was certified organic material from poultry manure (Perdue AgriRecycle, Seaford, DE; 4N-2P-3K analysis; Mays, 2013). The originally selected commercial fertilizer production was subsequently discontinued and an alfalfa-based commercial organic product (Bradfield Organics, Feed Solutions, St. Louis, MO; 3N-1P-5K analysis; Mays, 2013) was applied beginning in 2012. The composted poultry litter was obtained from a local source (Mays, 2013). The only nutrition the non-fertilized control treatments received came from the GMS treatments. Nutrient source treatments of the commercial fertilizer and poultry litter were applied at $50 \mathrm{~g}$ of actual nitrogen per tree per year in March of each year before application of the GMS treatments.

Soil samples were collected from the treatment area underneath the tree canopy from the top $10 \mathrm{~cm}$ in Mar. 2012, after 6 consecutive years of consistent management but before the 2012 applications, oven-dried at $105{ }^{\circ} \mathrm{C}$ for $24 \mathrm{~h}$, and ground and sieved through a 2-mm mesh screen. Subsamples were burned in a muffle furnace at $500{ }^{\circ} \mathrm{C}$ for $6 \mathrm{~h}$ for SOM concentration determination by loss-on-ignition.

Four soil core samples $(5.4 \mathrm{~cm}$ diameter) were collected from the top $6 \mathrm{~cm}$ in all treatment combinations in the organic orchard in June 2012 for BD and particle size analysis. Mulches were raked away to expose the mineral soil surface and rings were driven into the soil until the top edge of the ring was flush with the soil surface. Soil cores were dried for $3 \mathrm{~d}$ at $50{ }^{\circ} \mathrm{C}$ in a forced-air oven. Two cores were used to determine BD and soil from two cores was ground and sieved through a 2-mm screen for particle size analysis following the 2-h hydrometer method of Arshad et al. (1996).

Field moisture capacity and permanent wilting point water contents and saturated hydraulic conductivity $\left(\mathrm{K}_{\mathrm{sat}}\right)$ were estimated based on regression relationships established among soil particle size distribution, BD, and SOM (Saxton and Rawls, 2005). Measured sand, silt, and clay concentrations, $\mathrm{BD}$, and $\mathrm{SOM}$ concentration were used to estimate these variables on a plot-by-plot basis. Plant-available water was then calculated, on a plot-by-plot basis, as the difference between estimates of field moisture capacity and permanent wilting point.

Soil samples were also collected from the top $15 \mathrm{~cm}$ in Nov. 2011 using a 7.3-cm diameter core chamber and slide hammer to determine water-stable soil aggregates. Soil from all replications of the treatment combinations on the Pickwick soil was sampled (i.e., four of six total blocks). Replications on the Captina series were not evaluated for this portion of the study as a result of the close similarities between the Captina and Pickwick soils. Groundcovers were raked away to expose the mineral soil, and two cores were extracted from beneath each treatment tree. Each core was divided in half resulting in a $0-$ to $7.5-\mathrm{cm}$ surface layer and 7.5- to $15-\mathrm{cm}$ subsurface layer. The respective layers from both replicate cores were mixed, constituting an upper depth and lower depth sample for each plot, and passed through a $6.35-\mathrm{mm}^{2}$ screen before drying. Samples were subsequently air-dried for $5 \mathrm{~d}$ in a ventilated greenhouse and stored in unsealed plastic bags until wet sieving was conducted. Moisture content was not determined before wet sieving; however, it was assumed that all samples had air-dried to roughly the same water content. All soil sampling was conducted within $0.75 \mathrm{~m}$ of the treatment tree trunk.

Wet sieving followed the procedure described by Yoder (1936) and recently used by Brye and Riley (2009) for soils from the Ozark Highlands. The wet-sieving apparatus consisted of a $31-\mathrm{cm}$ wide $\times 76-\mathrm{cm}$ tall polyvinyl chloride column and an electric motor, which powered a plunge arm. A set of nested sieves with mesh openings of $4,2,1$, 0.5 , and $0.25 \mathrm{~mm}$ was attached to the plunge arm and adjusted to its bottom reach inside the cylinder. Water was added to the cylinder to the depth of the upper rim of the top sieve. Approximately $300 \mathrm{~g}$ of air-dried soil were weighed and placed in the top sieve. Wet sieving was allowed to proceed for $5 \mathrm{~min}$ at 130 cycles/min. While wet sieving occurred, successively smaller mineral soil particles and water-stable soil aggregates passed through the screens until the aggregate or mineral soil particle size exceeded the screen size. Water-stable aggregates and mineral soil particles less than $0.25 \mathrm{~mm}$ in diameter were collected at the bottom of the water cylinder. After $5 \mathrm{~min}$, the wet-sieve apparatus was stopped and the sieves were removed from the water column. The contents of each sieve were rinsed individually into small, aluminum sample tins. Because each GMS was replicated in triplicate blocks with nutrient source treatments, samples were sieved in triplicate according to GMS and soil depth and nutrient treatment, and the water column was drained and refilled between samples from different groundcover treatment samples.

All sample tins and their contents were placed into an $80^{\circ} \mathrm{C}$ forced-air oven for $24 \mathrm{~h}$. On removal from the oven, coarse fragments were removed by hand from the tins containing the contents of the 4- and 2-mm mesh screens, and the tins and contents were weighed. Because potential coarse fragments retained on the remaining screens were too small to remove by hand, the mass of material remaining on the 1-, 0.5-, and $0.25-\mathrm{mm}$ mesh screens reflects that of any small coarse fragments and actual water-stable aggregates. Total water-stable soil macroaggregate fraction was calculated as the sum of aggregate masses retained on each sieve divided by the initial air-dry soil mass. Size-separated, water-stable soil macroaggregate fraction was calculated as the mass of aggregates retained on each sieve divided by the initial air-dry soil mass.

To assess GMS effects on water movement, surface infiltration rates were measured in May 2012. On 18 May, tree rows were irrigated for $8 \mathrm{~h}$ at the rate of $45 \mathrm{~L} \cdot \mathrm{h}^{-1}$ to achieve relatively uniform soil moisture conditions. Infiltration measurements were conducted on 21 May from treatment combinations on the Pickwick soil and on 22 May from treatment combinations on the Captina soil. Only the non-fertilized GMS treatment combinations were selected for infiltration measurements. Infiltration data were collected using a double-ring infiltrometer with an inner ring diameter of $16 \mathrm{~cm}$. Surface mulches were removed at a distance of 0.5 to $1 \mathrm{~m}$ from the trunk under the canopy of treatment trees to expose the mineral soil surface. Vegetation growing in the mow-blow treatment was removed with a string trimmer to expose the mineral soil surface. As a result of the presence of rodent burrowing under the shredded paper treatments, an area void of burrows at the soil surface was selected as the representative portion of the tree row for infiltration measurements.

Infiltration measurements were performed using the technique outlined by Reynolds et al. (2002). Initial soil volumetric water contents were determined immediately after mulch removal by the average of three measurements using a Field Scout TDR300 soil moisture meter (Spectrum Technologies, Inc., Plainfield, IL) equipped with $6-\mathrm{cm}$ long probes. The outer ring of the infiltrometer was filled to within $\approx 1 \mathrm{~cm}$ of the top of the ring. The inner ring was then filled, and the water height was immediately recorded. Water height measurements were subsequently recorded at $1,3,6,9,12,15$, and up to 18 min if complete infiltration did not occur earlier. The average infiltration rate over the entire $18 \mathrm{~min}$ allowed for infiltration and the specific infiltration rate, determined based on the time required for all water to drain from the infiltrometer if that occurred before the 18-min mark, were calculated.

Statistical analyses were performed on soil quality-related measured variables using the PROC MIXED procedure in SAS (Version 9.2; SAS Institute Inc., Cary, NC). Analysis of variance (ANOVA) was used to evaluate the effects of GMS (whole-plot factor), nutrient source (split-plot factor), and their interaction on SOM concentration, $\mathrm{BD}$, and estimated field moisture capacity, permanent wilting point, plant available water, and $\mathrm{K}_{\mathrm{sat}}$. An ANOVA was conducted to evaluate the effects of GMS (whole-plot factor), nutrient source (split-plot factor), soil depth (split-split-plot factor), and their interactions on total water-stable aggregate fractions. An ANOVA was conducted to evaluate the effects of GMS (whole-plot factor), nutrient source (split-plot factor), soil depth (split-split-plot factor), aggregate size class (split-split-split-plot factor), and their interactions on water-stable aggregate fractions. An ANOVA was conducted to evaluate the effect of GMS on average and specific water infiltration rates using the GLM procedure in SAS. When appropriate, means were separated by the least significant difference at the 0.05 level. 
In addition, an analysis of covariance was conducted to evaluate the effects of GMS on the relationship between natural log-transformed infiltration rate and time. As a result of large expected inherent variability associated with soil hydraulic properties, significance was judged at the 0.1 level for all infiltration data analyses.

A conventionally managed orchard, established in 1989 and used for cultivar evaluation trials through 2012, was located on the same Pickwick and Captina soils $\approx 20 \mathrm{~m}$ from the organic orchard. Because the conventionally managed orchard was not included as part of the organic orchard research project, a formal statistical comparison was not conducted between data collected from each site. However, because no organic amendments had been added to the conventional orchard after its establishment, qualitative inferences were drawn regarding the effects of GMS on soil quality indicators as evaluated in both orchards.

Competitive vegetation management within the tree row in the conventional orchard consisted of pre-emergence and contact herbicide applications made as needed three to five times annually. Water-soluble, inorganic fertilizers, generally ammonium nitrate, were applied annually at rates of 50 to $75 \mathrm{~g}$ nitrogen per tree based on annual foliar nutrient analyses. Synthetic insecticides and fungicides were applied as needed using integrated pest management protocols at commercially recommended application rates and timing intervals (University of Arkansas Cooperative Extension Service, 2013a, 2013b). Before 2012, irrigation had been applied, but trees were not irrigated in 2012 in the conventional orchard.

Soil organic matter, BD, field moisture capacity, permanent wilting point, plantavailable water, $\mathrm{K}_{\mathrm{sat}}$, and water-stable soil aggregation were determined in the conventional orchard on the same dates and using the same methods as previously described for the organic orchard. Because the conventionally managed orchard was not irrigated in 2012, infiltration measurements were delayed until after rainfall occurred to approximate soil moisture conditions created in the organic orchard after irrigation. Infiltration was measured on 6 June 2012, $2 \mathrm{~d}$ after a $4.8-\mathrm{cm}$ precipitation event. All data analyses from the conventional orchard were limited to descriptive statistics, including means and standard errors.

\section{Results and Discussion}

Soil organic matter has often used as a soil quality indicator (Fliebach et al., 2006; Granatstein and Mullinix, 2008; Gregorich et al., 1994; Karlen et al., 1992; Loveland and Webb, 2003; Merwin et al., 1994, 1995), and changes in SOM have been linked to changes in other soil properties and processes. The near-surface SOM, total $\mathrm{C}$, and total nitrogen $(\mathrm{N})$ concentrations and contents, $\mathrm{C}: \mathrm{N}$ ratios, and $\mathrm{BD}$ did not differ $(P>$ 0.05 ) among GMS-nutrient source treatment combinations at the initiation of the study (Mays, 2013) indicating that soil conditions were as uniform throughout the study area as could reasonably be expected at the time of organic orchard establishment. Therefore, it was reasonably assumed that differences observed among treatments over the subsequent years were the result of the treatments rather than inherent differences.

Previously, we have reported that SOM in the top $10 \mathrm{~cm}$ increased over time in all GMS with the largest increase occurring in the green compost treatment (Mays et al., 2014). Furthermore, despite initial uniformity in 2006 before planting where SOM concentration averaged $1.5 \%$ across all treatments, by 2012, SOM concentration differed among nutrient sources within GMS (Mays et al., 2014). Soil organic matter concentration was greater across all nutrient sources in the green compost compared with the same nutrient source in each of the other three GMS. Whereas differences in SOM concentration among nutrient sources within the other three GMS were relatively minor (i.e., less than $0.7 \%$ ), SOM concentration under green compost was $1.3 \%$ lower with poultry litter than the commercial fertilizer and the non-fertilized control, which did not differ (Mays et al., 2014). Previous studies have also shown that integrated or organic orchard floor management practices using living and plant residue-based groundcovers increase SOM. Wells (2011) determined the combination of poultry litter and crimson clover (Trifolium incarnatum L.) increased SOM compared with an untreated control in pecan [Carya illinoeninsis (Wangenh.) K. Koch] production. Deurer et al. (2009) determined that soil organic $\mathrm{C}$ was $32 \%$ greater in the top $10 \mathrm{~cm}$ of an organically managed apple orchard receiving annual applications of compost than that in an integrated orchard in which herbicides were used to control competitive vegetation. Peck et al. (2011) documented greater SOM accumulation in an integrated apple orchard receiving bark mulch applications and occasional herbicide applications than in an organically managed apple orchard treated with tillage and composted poultry litter. Conversely, Merwin et al. (1995) observed no differences in SOM concentrations between plant-based mulches and tree rows receiving plastic mulches and managed with herbicides.

Similar to SOM, soil BD measured at orchard establishment in 2006 was unaffected by GMS or nutrient source and averaged $1.34 \mathrm{~g} \cdot \mathrm{cm}^{-3}$; however, in contrast to SOM, BD decreased in all GMS treatments over time in the first 6 years of the study (Mays, 2013). We have reported that BD differed among GMS and among nutrient sources after 6 years of consistent management (Mays et al., 2014). In 2012, averaged across nutrient sources, BD was greater $(P=$ $0.016)$ under shredded paper and mow-blow $\left(1.15 \mathrm{~g} \cdot \mathrm{cm}^{-3}\right)$, which did not differ, than under wood chips and green compost (1.01 $\mathrm{g} \cdot \mathrm{cm}^{-3}$ ), which did not differ. Nutrient source also affected BD. Averaged over GMS, soil $\mathrm{BD}$ was lowest from commercial organic fertilizer applications (1.03 $\left.\mathrm{g} \cdot \mathrm{cm}^{-3}\right)$ and differed $(P=0.022)$ from that in the non-fertilized control $\left(1.12 \mathrm{~g} \cdot \mathrm{cm}^{-3}\right)$. Although Granatstein and Mullinix (2008) did not observe differences in BD between organic and conventionally managed orchards, other studies have shown that organic orchard floor management practices can result in decreased soil BD. Glover et al. (2000) and Goh et al. (2001) reported decreased BD in organic apple orchards implementing mulches as an orchard floor management tool. Deurer et al. (2009) observed greater macroporosity in an organic apple orchard receiving compost and maintained under grass cover than in an integrated system using herbicides for orchard floor management. Results were attributed to the activity of roots and soil fauna as well as increases in soil aggregate stability, microbial biomass, and subsequent increases in macropore stability (Deurer et al., 2009). In the present study, decreases in BD since 2006 were attributable to a dilution of the mineral soil component with organic residues and aggregation of soil within the top $6 \mathrm{~cm}$, although burrowing animals and soil macrofauna may have also contributed.

Soil water characteristics are related to soil texture (i.e., the distribution of sand, silt, and clay). Although no differences were observed in clay concentration and a few minor, yet nonagronomically significant differences in sand and silt concentration among GMS treatments were observed (Mays, 2013). Therefore, it was concluded that minute differences in the sand and silt fractions did not vary appreciably among treatment combinations and the relatively large differences in estimated soil water characteristics were attributed to treatment effects on other soil quality factors such as SOM.

Estimated field moisture capacity, permanent wilting point, and plant-available water in the top $10 \mathrm{~cm}$ differed among nutrient sources within GMS treatments $(P<0.002)$. The estimated volumetric water content at field moisture capacity was greater under green compost with commercial fertilizer and in the non-fertilized control $(26.2 \%)$ than in any other treatment combination, which ranged from $21.1 \%$ in the wood chips with commercial fertilizer to $22.6 \%$ in the green compost with poultry litter (Table 1). Similarly, estimated volumetric water content at permanent wilting point was greater under green compost with commercial fertilizer treatments and in the non-fertilized control $(8.4 \%)$ than in any other treatment combination, which ranged from $4.7 \%$ in the non-fertilized mow-blow to $6.7 \%$ in the green compost with poultry litter (Table 1).

Consequently, plant-available water, determined as the difference in the water contents at field moisture capacity and permanent wilting point, was greatest under green compost with commercial fertilizer and in the non-fertilized control $(17.9 \%)$ than in any other treatment combination, which ranged from $15.9 \%$ in the wood chips with commercial fertilizer to $17.0 \%$ in the mow-blow with poultry litter (Table 1). 
Table 1. Summary of the effects of groundcover management system (GMS) and nutrient source treatments on estimated field moisture capacity, permanent wilting point, plant-available water, and saturated hydraulic conductivity of the top $10 \mathrm{~cm}$ in an organically managed apple orchard on a siltloam soil in the Ozark Highlands of northwest Arkansas. ${ }^{\mathrm{z}}$

\begin{tabular}{lccc}
\hline & & \multicolumn{2}{c}{ Nutrient source treatment } \\
\cline { 2 - 4 } Estimated soil property/GMS & Non-fertilized & Poultry litter & Commercial fertilizer \\
\hline Field moisture capacity (\%) & $21.6 \mathrm{~B}^{\mathrm{y}} \mathrm{a}^{\mathrm{x}}$ & $21.8 \mathrm{ABa}$ & $21.8 \mathrm{Ba}$ \\
Shredded paper & $22.0 \mathrm{Bab}$ & $22.8 \mathrm{Aa}$ & $21.1 \mathrm{Bb}$ \\
Wood chips & $21.8 \mathrm{Ba}$ & $21.4 \mathrm{Ba}$ & $21.4 \mathrm{Ba}$ \\
Mow-blow & $26.3 \mathrm{Aa}$ & $22.6 \mathrm{ABb}$ & $26.2 \mathrm{Aa}$ \\
Green compost & & & $5.1 \mathrm{Ba}$ \\
Permanent wilting point (\%) & $5.2 \mathrm{Ba}$ & $5.2 \mathrm{Ba}$ & $5.1 \mathrm{Bb}$ \\
Shredded paper & $5.5 \mathrm{Bab}$ & $6.2 \mathrm{Aa}$ & $4.9 \mathrm{Ba}$ \\
Wood chips & $4.7 \mathrm{Ba}$ & $4.8 \mathrm{Ba}$ & $8.5 \mathrm{Aa}$ \\
Mow-blow & $8.3 \mathrm{Aa}$ & $6.7 \mathrm{Ab}$ & $16.7 \mathrm{Ba}$ \\
Green compost & & & $15.9 \mathrm{Ba}$ \\
Plant-available water (\%) & $16.4 \mathrm{Ba}$ & $16.7 \mathrm{ABa}$ & $16.5 \mathrm{Ba}$ \\
Shredded paper & $16.5 \mathrm{Ba}$ & $16.6 \mathrm{ABa}$ & $17.7 \mathrm{Aa}$ \\
Wood chips & $16.7 \mathrm{Ba}$ & $17.0 \mathrm{Aa}$ & \\
Mow-blow & $18.1 \mathrm{Aa}$ & $16.0 \mathrm{Bb}$ & $67.0 \mathrm{Ba}$ \\
Green compost & & $64.6 \mathrm{Bab}$ \\
Saturated hydraulic conductivity $\left(\mathrm{mm} \cdot \mathrm{h}^{-1}\right)$ & $57.7 \mathrm{Ba}$ & $60.6 \mathrm{Ba}$ & $51.7 \mathrm{Ca}$ \\
Shredded paper & $57.8 \mathrm{Bb}$ & $68.2 \mathrm{Ba}$ & $102.6 \mathrm{Aa}$ \\
Wood chips & $57.1 \mathrm{Ba}$ & $60.4 \mathrm{Ba}$ & $86.1 \mathrm{Ab}$ \\
Mow-blow & $100.0 \mathrm{Aa}$ & & \\
Green compost & & & \\
\hline
\end{tabular}

${ }^{\mathrm{z}}$ Estimates of soil water characteristics were derived from Saxton and Rawls (2005).

${ }^{y}$ Means within a column for nutrient source treatment for a particular property followed by different upper case letters are significantly different at the 0.05 level. $\mathrm{n}=6$.

${ }^{x}$ Means within a GMS across nutrient sources followed by different lower case letters are significantly different at the 0.05 level. $\mathrm{n}=6$.

These results follow the treatment effects on SOM concentration among GMS and nutrient source treatment combinations (Mays et al., 2014). These results also corroborate the assertion of Hudson (1994) that increased SOM may correspond to increased plant-available water. Deurer et al. (2008) determined that plant-available water was slightly greater deeper in the soil profile than in the top $10 \mathrm{~cm}$ under organic orchard management. Greater soil water availability was observed with wood chip applications or under straw mulch compared with other groundcover management options (Merwin et al., 1994, 1995). Emerson (1995) concluded that increases in soil water content were correlated to the magnitude of soil $\mathrm{C}$ change resulting from storage of water in polysaccharide gels. Results of this study support previous work suggesting water availability is positively affected by organic production methods and subsequent increases in soil C levels (Mays, 2013).

Saturated hydraulic conductivity in the top $10 \mathrm{~cm}$ was also estimated in a similar manner as were field moisture capacity and permanent wilting point. Similar to other soil water characteristics, $\mathrm{K}_{\mathrm{sat}}$ also differed among nutrient sources within GMS $(P<0.004)$. Estimated $\mathrm{K}_{\mathrm{sat}}$ was greater under green compost with commercial fertilizer and in the non-fertilized control $\left(101.3 \mathrm{~mm} \cdot \mathrm{h}^{-1}\right)$ than in any other treatment combination, which ranged from $51.7 \mathrm{~mm} \cdot \mathrm{h}^{-1}$ in the mow-blow with commercial fertilizer to $86.1 \mathrm{~mm} \cdot \mathrm{h}^{-1}$ in the green compost with poultry litter (Table 1). Although saturated soil conditions are unlikely to exist for any length of time in an orchard, knowledge of water movement during saturated soil conditions may be helpful aggregates in the greater than 4-mm size class were not included in the subsequent analysis. In the top $7.5 \mathrm{~cm}$, water-stable aggregate fraction in each size class was always greater under green compost than under any other GMS with the exception that water-stable aggregate fraction under shredded paper was similar to that under green compost in the 0.25 - to $0.5-\mathrm{mm}$ size class (Table 2). Although less total residue was applied, water-stable aggregation was greater in soil under shredded paper than under wood chips in the upper $7.5 \mathrm{~cm}$. This observation could be the result of the rate at which the shredded paper mulch decomposed with a greater portion of the shredded paper visibly decaying by the end of each growing season compared with the wood chips, thereby contributing more $\mathrm{C}$ to the soil food web to contribute to soil aggregate formation.

Water-stable aggregate fraction was generally greater in the top $7.5 \mathrm{~cm}$ than in the 7.5 to $15-\mathrm{cm}$ soil depth (Table 2). Furthermore, water-stable aggregate fraction was also greater in the 0.25 - to $0.5-\mathrm{mm}$ size class in the top $7.5 \mathrm{~cm}$ than in any other size class and tended to decrease as aggregate size class increased (Table 2). These results were similar to that reported by Motschenbacher (2012) and Smith (2013) for fine-textured alluvial soils in the Mississippi River Delta region of eastern Arkansas under row-crop cultivation. Although other differences in water-stable aggregate fraction existed among GMS within the four aggregate size classes, differences were always less than $0.02{\mathrm{~g} . \mathrm{g}^{-1}}^{-1}$ (Table 2). Similar to that for total water-stable aggregate fraction, there were no differences in water-stable aggregate fraction among GMS within any aggregate size class although in total, green compost treatments resulted in greater aggregation than mow and blow treatments (Table 2).

Tisdall and Oades (1982) suggested that macroaggregates larger than $2 \mathrm{~mm}$ are held together by fine roots and hyphae in soils with more than $2 \%$ organic matter. Green compost treatments contained the greatest SOM concentration $(5.6 \%)$ of all GMS, a condition that correlates to greater aggregate stability (Lado et al., 2004). As a result of prior composting activity and its low $\mathrm{C}: \mathrm{N}$ ratio (Mays, 2013), green compost may have been humidified and incorporated into the rhizosphere more quickly than other GMS treatments included in this study, thereby stimulating enough growth of fine roots and fungi whose hyphae readily enmeshed smaller aggregates (Jastrow and Miller, 1998). Because of its composted nature, the physical and chemical characteristics of the green compost should have allowed greater soil micro-organism activity, thereby increasing production of polysaccharide gels important to the formation of water-stable aggregates (Kay, 1998). On the contrary, all other GMS had a larger $\mathrm{C}: \mathrm{N}$ ratio than the green compost (Mays, 2013), and when applied at the mulching rates used in this study, soil microbial activity may have been reduced as a result of $\mathrm{N}$ immobilization, thereby limiting 


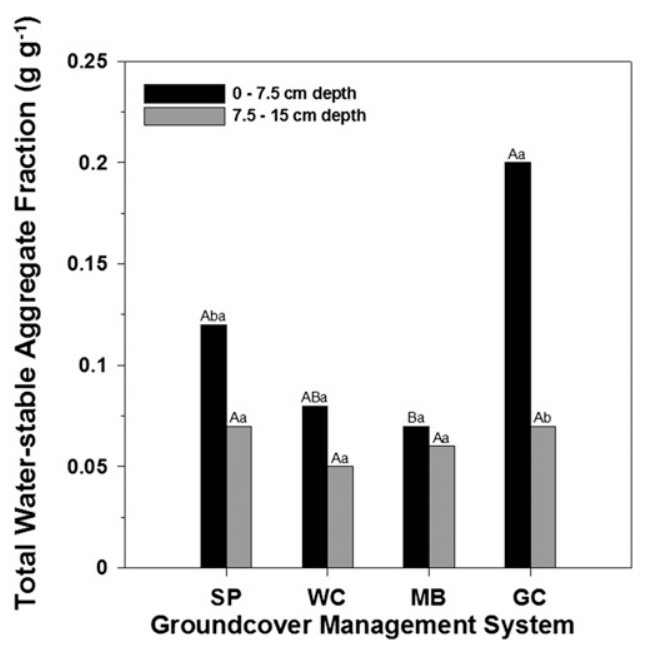

Fig. 1. Total water-stable soil aggregate fraction as affected by groundcover management system [GMS; shredded paper (SP), wood chips (WC), mow-blow (MB), and green compost (GC)] and soil depth in an organically managed apple orchard in the Ozark Highlands region of northwest Arkansas. Means with different upper case letters atop bars within the same soil depth across GMS are significantly different at the 0.05 level. Means with different lower case letters atop bars within the same GMS between soil depths are significantly different at the 0.05 level. $n=4$.

Table 2. Summary of the effects of groundcover management system (GMS), soil depth, and size class on water-stable soil aggregate fractions in an organically managed apple orchard on a silt-loam soil in the Ozark Highlands of northwest Arkansas.

\begin{tabular}{lccccc}
\hline & & \multicolumn{4}{c}{ Water-stable aggregate fraction $\left(\mathrm{g} \cdot \mathrm{g}^{-1}\right)$} \\
\cline { 3 - 6 } GMS & Depth & 0.25 to $0.5 \mathrm{~mm}$ & 0.5 to $1 \mathrm{~mm}$ & 1 to $2 \mathrm{~mm}$ & Greater than $2 \mathrm{~mm}$ \\
\cline { 3 - 6 } & 0 to $7.5 \mathrm{~cm}$ & $0.06 \mathrm{~A}^{\mathrm{z}} \mathrm{a}^{\mathrm{y}} \alpha^{\mathrm{x}}$ & $0.04 \mathrm{Ba} \beta$ & $0.02 \mathrm{Ba} \gamma$ & $0.001 \mathrm{Ba} \delta$ \\
Shredded paper & 7.5 to $15 \mathrm{~cm}$ & $0.03 \mathrm{Ab} \alpha$ & $0.02 \mathrm{Ab} \beta$ & $0.01 \mathrm{Aa} \beta$ & $<0.001 \mathrm{Aa} \gamma$ \\
Wood chip & 0 to $7.5 \mathrm{~cm}$ & $0.04 \mathrm{Ba} \alpha$ & $0.02 \mathrm{BCa} \beta$ & $0.02 \mathrm{Ba} \beta$ & $0.002 \mathrm{Ba} \gamma$ \\
& 7.5 to $15 \mathrm{~cm}$ & $0.03 \mathrm{Ab} \alpha$ & $0.02 \mathrm{Aa} \beta$ & $0.01 \mathrm{Aa} \beta$ & $<0.001 \mathrm{Aa} \gamma$ \\
Mow-blow & 0 to $7.5 \mathrm{~cm}$ & $0.04 \mathrm{Ba} \alpha$ & $0.02 \mathrm{Ca} \beta$ & $0.02 \mathrm{Ba} \beta$ & $<0.001 \mathrm{Ba} \gamma$ \\
Green compost & 7.5 to $15 \mathrm{~cm}$ & $0.03 \mathrm{Ab} \alpha$ & $0.02 \mathrm{Aa} \beta$ & $0.01 \mathrm{Aa} \beta$ & $<0.001 \mathrm{Aa} \gamma$ \\
& 0 to $7.5 \mathrm{~cm}$ & $0.06 \mathrm{Aa} \alpha$ & $0.05 \mathrm{Aa} \beta$ & $0.06 \mathrm{Aa} \alpha \beta$ & $0.03 \mathrm{Aa} \gamma$ \\
& 7.5 to $15 \mathrm{~cm}$ & $0.03 \mathrm{Ab} \alpha$ & $0.02 \mathrm{Ab} \beta$ & $0.02 \mathrm{Ab} \beta$ & $0.001 \mathrm{Ab} \gamma$ \\
\hline
\end{tabular}

${ }^{\mathrm{z}}$ Means within a column for the same soil depth followed by different upper case letters are significantly different at the 0.05 level. $\mathrm{n}=4$.

${ }^{\mathrm{y}}$ Means within a column between soil depths within the same GMS followed by different lower case letters are significantly different, 0.05 level. $\mathrm{n}=4$.

${ }^{x}$ Means among size classes within the same GMS and the same soil depth followed by different Greek letters are significantly different at the 0.05 level. $n=4$.

bacterial-induced water-stable aggregate formation in the three GMS other than green compost.

Other studies have shown that applications of plant-based residues increase aggregate stability in orchard soils. Peck et al. (2011) observed greater aggregate stability under bark mulches. Glover et al. (2000) also observed increases in soil aggregation in an integrated apple production system that used bark mulch and limited herbicide application over conventional management implementing herbicide applications. Similarly, Deurer et al. (2008) showed greater aggregate stability with an organic production system and compost applications than with an integrated orchard floor managed by herbicide applications. Like in the present study, the findings of Glover et al. (2000) suggested GMS systems that protect the soil surface with relatively large amounts of organic residues can lead to increased formation of water-stable aggregates. Orchard floor management systems a greater infiltration rate after shredded paper treatment than after other mulch treatments. However, infiltration rates after wood chip treatment did not differ from that after shredded paper treatment (Granatstein and Mullinix, 2008).

The relationship between infiltration rate and time followed an expected pattern, starting high and exponentially decreasing over time for all four GMS. Analysis of covariance revealed that GMS did not affect $(P>0.05)$ the slope of the relationship between natural log-transformed infiltration rate and time. However, the intercept of the relationship between natural log-transformed infiltration rate and time differed $(P<0.05)$ among GMS, indicating the initial infiltration rates varied among GMS treatments immediately after infiltration began. Similar to specific infiltration rates, wood chip applications resulted in the smallest intercept (i.e., slowest initial infiltration rate), whereas intercepts were larger and similar among the other three GMS.

Observable differences were noted in the greater number of shredded paper plots that had complete infiltration within 18 min compared with the other GMS. Visible differences in soil structure were noted under shredded paper and green compost with both having a more granular appearance than that observed under wood chips and mow-blow treatments.

The shredded paper GMS appeared to provide a habitat preferred by rodents, as evidenced by apparent increased burrowing observed under shredded paper than under the other three GMS (data not presented). This concurs with an increase in vole tree damage under the mow-blow and paper GMS compared with wood chips (Rom, personal communication). Merwin et al. (1999) observed significant meadow vole (Microtus pennsylvanicus Ord.) activity when straw mulch and crown vetch (Coronilla varia L.) were used as a GMS compared with orchard floor management including herbicide applications, managed sod production, and tillage, indicating rodents may prefer burrowing beneath lighter weight groundcovers. The significantly and numerically greater specific infiltration rate under shredded paper and green compost, respectively, than under wood chips and mow-blow were similar to the results observed for waterstable soil aggregation (Fig. 1; Table 2) demonstrating that greater aggregation leads to greater infiltration.

At the time infiltration measurements were conducted, more earthworms were observed under the shredded paper and green compost mulches than under wood chips and mowblow treatments, which may have contributed to the results of this study (Lee and Foster, 1991). Deurer et al. (2009) attributed increased incidence of stable macropore formation attributable in part to greater earthworm tunneling in an organically managed orchard compared with an integrated system using herbicides for management of weed growth. Similarly, Jamar et al. (2010) and van Rhee (1977) 
documented increased earthworm abundance when application of agricultural chemicals was minimized, like in organic production.

Increasing the amount of water entering the soil profile decreases the likelihood of runoff during heavy rain events, and greater use of rainfall is advantageous for reducing or delaying irrigation. Groundcovers increase the roughness of the soil surface, slowing the movement of water, and permitting more water to enter the soil. Groundcover management systems may also contribute to increased infiltration rates by creating conditions promoting macrofaunal colonization of the rhizosphere and, as a result, stimulate macropore formation. Considering GMS affected infiltration, more efficient use of rainfall and irrigation would also be expected when using organic orchard floor management practices that include mulches (Goh et al., 2001; Merwin et al., 1994; Reganold et al., 2001).
Comparisons to an adjacent conventional orchard. Although not a formal, statistical component of this field study, the adjacent conventionally managed orchard offers a unique opportunity to make comparisons to organic orchard management. After seven seasons of organic management, the SOM concentration in the top $10 \mathrm{~cm}$ under green compost in the organic orchard was numerically double that in the adjacent conventionally managed orchard, whereas SOM under all other organic GMS were similar to that in the conventional orchard (Table 3 ). It is noted that the SOM in the conventionally managed orchard and treatments other than green compost were relatively low $\left(0.03 \mathrm{~g} \cdot \mathrm{g}^{-1}\right)$. The lack of SOM contribution from the paper mulch was expected because it tended to break down and decay on the soil surface, almost disappearing by the end of the season. The wood chips GMS treatment resulted in a season-to-season remaining detritus under

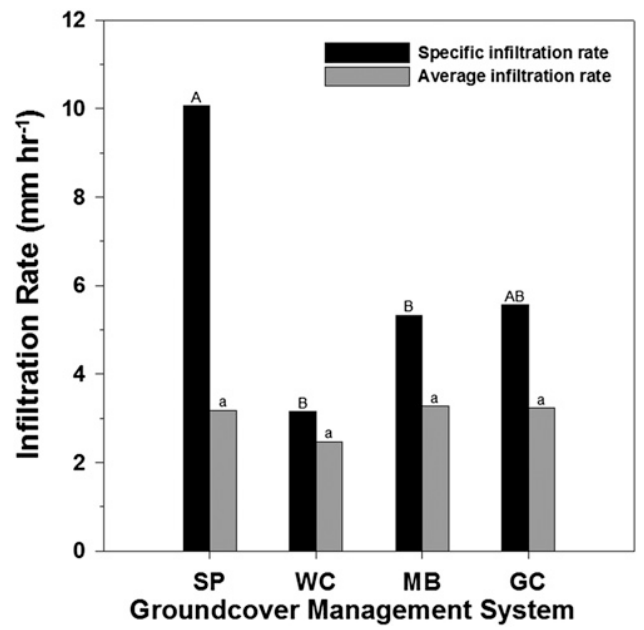

Fig. 2. The influence of groundcover management system [GMS; shredded paper (SP), wood chips (WC), mow-blow (MB), and green compost (GC)] on the specific infiltration rate, determined based on the actual time it took for all initial water to infiltrate up to $18 \mathrm{~min}$, and average infiltration rate, determined based on the 18-min duration of the infiltration experiment, in an organically managed apple orchard in the Ozark Highlands region of northwest Arkansas. Means with different upper case letters atop bars for specific infiltration rate are significantly different at the 0.05 level. Means with different lower case letters atop bars for average infiltration rate are significantly different at the 0.05 level. $\mathrm{n}=6$.

Table 3. Informal comparison of soil quality indicators among four groundcover management systems [i.e., shredded paper (SP), wood chips (WC), mow-blow (MB), green compost (GC)] in an organically managed with that from an adjacent conventionally managed apple orchard on a silt-loam soil in the Ozark Highlands region of northwest Arkansas. ${ }^{z}$

\begin{tabular}{|c|c|c|c|c|c|}
\hline \multirow[b]{2}{*}{ Soil quality indicator } & \multicolumn{4}{|c|}{ Groundcover management system in organic orchard } & \multirow[b]{2}{*}{ Conventional orchard } \\
\hline & SP & $\mathrm{WC}$ & MB & $\mathrm{GC}$ & \\
\hline $\operatorname{SOM}\left(g \cdot g^{-1}\right)$ & $0.03(<0.01)$ & $0.03(<0.01)$ & $0.03(<0.01)$ & $0.06(<0.01)$ & $0.03(<0.01)$ \\
\hline $\mathrm{BD}\left(\mathrm{g} \cdot \mathrm{cm}^{-3}\right)$ & $1.13(0.03)$ & $1.01(0.04)$ & $1.17(0.02)$ & $1.02(0.02)$ & $1.3(0.03)$ \\
\hline FMC $(\%)$ & $21.7(0.3)$ & $22.0(0.4)$ & $21.5(0.2)$ & $25.1(0.6)$ & $22.3(0.4)$ \\
\hline PWP (\%) & $5.1(0.2)$ & $5.6(0.4)$ & $4.8(0.3)$ & $7.8(0.4)$ & $5.1(0.4)$ \\
\hline PAW (\%) & $16.6(0.1)$ & $16.4(0.2)$ & $16.7(0.1)$ & $17.3(0.4)$ & $17.2(0.3)$ \\
\hline $\mathrm{K}_{\mathrm{sat}}\left(\mathrm{mm} \cdot \mathrm{h}^{-1}\right)$ & $61.8(2.3)$ & $63.5(3.5)$ & $56.4(2.4)$ & $96.2(3.4)$ & $53.1(2.9)$ \\
\hline $\mathrm{WSA}_{0-7.5 \mathrm{~cm}}\left(\mathrm{~g} \cdot \mathrm{g}^{-1}\right)$ & $0.12(0.01)$ & $0.08(0.01)$ & $0.07(0.01)$ & $0.2(0.03)$ & $0.06(<0.01)$ \\
\hline $\mathrm{WSA}_{7.5-15 \mathrm{~cm}}\left(\mathrm{~g} \cdot \mathrm{g}^{-1}\right)$ & $0.07(<0.01)$ & $0.05(0.01)$ & $<0.01(<0.01)$ & $0.07(0.01)$ & $0.06(<0.01)$ \\
\hline IR_0 $\left(\mathrm{mm} \cdot \mathrm{min}^{-1}\right)$ & $10.1(3.0)$ & $3.2(0.9)$ & $5.3(1.2)$ & $5.6(1.6)$ & $3.5(1.1)$ \\
\hline IR_18 $\left(\mathrm{mm} \cdot \mathrm{min}^{-1}\right)$ & $3.2(0.3)$ & $2.5(0.4)$ & $3.3(0.5)$ & $3.2(0.8)$ & $2.8(0.4)$ \\
\hline
\end{tabular}

${ }^{{ }^{2}}$ Soil quality indicators include soil organic matter (SOM) concentration, bulk density (BD), estimated field moisture capacity (FMC), permanent wilting point (PWP), plant-available water capacity (PAW), and saturated hydraulic conductivity $\left(\mathrm{K}_{\mathrm{sat}}\right)$; specific infiltration rate (IR_0) and average infiltration rate (IR_18); and total water-stable soil aggregate (WSA) concentrations from two soil depths. Estimates of soil water characteristics were derived from Saxton and Rawls (2005). Data shown are means $( \pm \mathrm{SE}) . \mathrm{n}=6$. the tree, which may over a longer time period contribute to increased SOM. Other studies have also demonstrated greater SOM under organic GMS than under conventional orchard management (Amiri and Fallahi, 2008; Glover et al., 2000; Reganold et al., 2001). Differences between this study and previous studies may be the result of the hot humid conditions of the test site resulting in greater organic matter turnover than in other sites reporting contradictory results.

Bulk density was numerically greater in the conventional orchard than in all GMS treatments (Table 3 ) indicating that porosity was lower in the conventionally managed system, which likely affects other soil properties and processes. Similar to SOM, field moisture capacity and permanent wilting point were numerically greater under green compost organic management than under conventional management, whereas that for the other three GMS were similar to under conventional management (Table 3). However, plant-available water was numerically larger and similar between green compost organic and conventional management than that in the other three organic GMS (Table 3). These results demonstrate the positive value of increasing SOM on soil water characteristics. Estimated $\mathrm{K}_{\text {sat }}$ was also nearly numerically double that under green compost than under conventional orchard management, whereas that under the other three organic GMS was numerically similar to that under conventional management (Table 3 ).

Total water-stable soil aggregate fraction in the top $7.5 \mathrm{~cm}$ of the soil profile was numerically greater for shredded paper and green compost in the organic orchard than in the conventional orchard (Table 3). Therefore, it is probable that aggregation in the conventional orchard was reduced as a result of the absence of annual additions of plant residues at the soil surface, which in turn reduced micro-organism and macrofaunal activity in the rhizosphere. Similarly, reduced soil aggregation in the conventional orchard may also be related to lower SOM (Carter, 2002). However, total water-stable aggregate fraction in the $7.5-$ to $15-\mathrm{cm}$ soil depth was similar among all organic GMS and the conventional orchard with the exception of that in the mow-blow GMS (Table 3).

Volumetric soil water contents determined in the conventional orchard before conducting infiltration measurements were comparable to values obtained in the organic orchard after an 8-h irrigation cycle; thus, infiltration rates measured in the conventional orchard were assumed to be justifiably comparable to those measured in the organic orchard. Specific and average infiltration rates associated with the shredded paper, mow-blow, and green compost treatments in the organic orchard were numerically greater than those measured in the conventional orchard. However, specific and average infiltration rates under wood chips were numerically lower than those measured in the conventional orchard. These results indicate that, with the exception of wood chip 
applications, organic GMS facilitate greater water infiltration than conventional orchard management.

\section{Conclusions}

The soil properties and processes evaluated collectively in this study demonstrate the effects and benefits of organic orchard floor management using various GMS and organic nutrient sources on near-surface soil quality under apple production in the Ozark Highlands region of northwest Arkansas and in comparable climates and soils. Significant changes in SOM concentration were achieved after only 6 years of consistent organic management as a result of application of GMS and nutrient source treatments, which consequently impacted all other soil quality indicators evaluated in this study. Nutrient source treatments positively affected some soil quality indicators, but their magnitude of impact and consistency were lower than for the GMS. Based on the results of this study, the addition of organic residues to an orchard floor benefits water-stable aggregate formation, and mulches with a low $\mathrm{C}: \mathrm{N}$ ratio show potential to benefit the orchard soil structure. Among the organic GMS, green compost had the greatest positive impact on soil quality of all treatment combinations investigated. Similarly, organic green compost often showed the largest benefit to soil quality compared with soil properties observed in the conventionally managed orchard. Increased infiltration rates, as observed for several organic GMS over the conventional management, may benefit orchard production during the hot, dry summer months in the Ozark Highlands. This study also demonstrates that the use of plant residue-based GMS favors soil aggregation in highly weathered, Ozark Highland soils and that soil structure may be improved relatively quickly as GMS materials decompose. Therefore, it appears that the GMS and nutrient source combinations evaluated in this study provide a viable set of management options for apple producers in the Ozark Highlands and similar regions while also satisfying the USDA-NOP requirement to simultaneously improve soil quality with crop production.

\section{Literature Cited}

Albrecht, W.A. and J. Sosne. 1944. Soil granulation and percolation rate as related to crops and manuring. J. Amer. Soc. Agron. 36:646-648.

Amiri, M.E. and E. Fallahi. 2008. Impact of animal manure on soil chemistry, mineral nutrients, yield, and fruit quality in 'Golden Delicious' apple. J. Plant Nutr. 32:610-617.

Arshad, M.A. and G.M. Coen. 1992. Characterization of soil quality: Physical and chemical criteria. Amer. J. Altern. Agr. 7:25-30.

Arshad, M.A., B. Lowery, and B. Grossman. 1996. Physical tests for monitoring soil quality, p. 123-141. In: Doran, J.W. and A.J. Jones (eds.). Methods for assessing soil quality. SSSA Spec. Publ. 49. SSSA, Madison, WI.

Bhogal, A., F.A. Nicholson, and B.J. Chambers. 2009. Organic carbon additions: Effects on soil bio-physical and physico-chemical properties. Eur. J. Soil Sci. 60:276-286.

Boyle, M., W.T. Frankenberger, Jr., and L.H. Stolzy. 1989. The influence of organic matter on soil aggregation and water infiltration. J. Prod. Agr. 2:290-299.

Brye, K.R., E. Mersiovsky, L. Hernandez, and L. Ward. 2013. Soils of Arkansas. Arkansas Agricultural Experiment Station, University of Arkansas System Division of Agriculture, Fayetteville, AR.

Brye, K.R. and T.L. Riley. 2009. Soil and plant property differences across a chronosequence of humid-temperature tallgrass prairie restorations. Soil Sci. 174:346-357.

Carter, M.R. 2002. Soil quality for sustainable land management: Organic matter and aggregation interactions that maintain soil functions. Agron. J. 94:38-47.

Celik, I., H. Gunal, M. Budak, and C. Akpinar. 2010. Effects of long-term organic and mineral fertilizers on bulk density and penetration resistance in semi-arid Mediterranean soil conditions. Geoderma 160:236-243.

Choi, H.S. 2009. Effects of different organic apple production systems on seasonal variation of soil and foliar nutrient concentration. $\mathrm{PhD}$ diss., Univ. Arkansas, Fayetteville, AR.

Deurer, M., D. Grinev, I. Young, B.E. Clothier, and K. Müller. 2009. The impact of soil carbon management on soil macropore structure: A comparison of two apple orchard systems in New Zealand. Eur. J. Soil Sci. 60:945-955.

Deurer, M., S. Sivakumaran, S. Ralle, I. Vogeler, I. McIvor, B. Clothier, S. Green, and J. Bachman. 2008. A new method to quantify the impact of soil carbon management on biophysical soil properties: The example of two apple orchard systems in New Zealand. J. Environ. Qual. 37:915-924.

Doran, J.W., M. Sarrantonio, and M.A. Liebeg. 1996. Soil health and sustainability, p. 1-54. In: Sparks, D.L. (ed.). Advances in agronomy. Vol. 56. Academic Press, San Diego, CA.

Emerson, W.R. 1995. Water retention, organic C and soil texture. Austral. J. Soil Res. 33:241251.

Fliebach, A., H.R. Oberholzer, L. Gunst, and P. Mäder. 2006. Soil organic matter and biological soil quality indicators after 21 years of organic and conventional farming. Agr. Ecosyst. Environ. 118:273-284.

Freebairn, D.M., S.C. Gupta, and W.J. Rawls. 1991. Influence of aggregate size and microrelief on development of surface soil crusts. Soil Sci. Soc. Amer. J. 55:188-195.

Glover, J.D., J.P. Reganold, and P.K. Andrews. 2000. Systematic method for rating soil quality of conventional, organic, and integrated apple orchards in Washington State. Agr. Ecosyst. Environ. 80:29-45.

Goh, K.M., D.R. Pearson, and M.J. Daly. 2001. Effects of apple orchard production systems on some important soil physical, chemical and biological quality parameters. Biol. Agr. Hort. 18:269-292.

Granatstein, D. and K. Mullinix. 2008. Mulching options for Northwest organic and conventional orchards. HortScience 43:45-50.

Gregorich, E.G., M.R. Carter, D.A. Angers, C.M. Monreal, and B.H. Ellert. 1994. Towards a minimum data set to assess soil organic matter quality in agricultural soils. Can. J. Soil Sci. 74:367-385.

Hudson, B.D. 1994. Soil organic matter and available water capacity. J. Soil Water Conserv. 49:189-194.

Jamar, L., H. Magein, and M. Lateur. 2010. Effect of organic farming practices on five orchard soil bio-indicators. In: Prange, R.K. and S.D. Bishop (eds.). Proc. Organic Fruit Conference. Acta Hort. 873, ISHS 2010.

Jastrow, J.D. and R.M. Miller. 1991. Methods for assessing the effects of biota on soil structure. Agr. Ecosyst. Environ. 34:279-303.

Jastrow, J.D. and R.M. Miller. 1998. Soil aggregate stabilization and carbon sequestration, p. 207223. In: Lal, R., J.M. Kimble, R.F. Follett, and B.A. Stewart (eds.). Soil processes and the carbon cycle. CRC Press, Boca Raton, FL.

Jordán, A., L.M. Zavala, and J. Gil. 2010. Effects of mulching on soil physical properties and runoff under semi-arid conditions in southern Spain. Catena 81:77-85.

Karlen, D.L., N.S. Nash, and P.W. Unger. 1992. Soil and crop management effects on soil quality and health. Amer. J. Altern. Agr. 7:48-55.

Kay, B.D. 1998. Soil structure and organic carbon: A review, p. 169-197. In: Lal, R., J.M. Kimble, R.F. Follett, and B.A. Stewart (eds.). Soil processes and the carbon cycle. CRC Press, Boca Raton, FL.

Kemper, W.D. and R.C. Rosenau. 1986. Aggregate stability and size distribution, p. 425-442. In: Methods of soil analysis, part 1 . Physical and mineralogical methods. Agronomy Monograph no. 9. 2nd Ed. Society of Agronomy/Soil Science Society of America, Madison, WI.

Kimble, J.M. 2007. On-farm benefits of carbon management: The farmers' perspectives, p. 45 65. In: Kimble, J.M., C.W. Rice, D. Reed, S. Mooney, R.F. Follett, and R. Lal (eds.). Soil carbon management: Economic, environmental and societal benefits. CRC Press, Boca Raton, FL.

Lado, M., A. Paz, and M. Ben-Hur. 2004. Organic matter and aggregate size interactions in infiltration, seal formation, and soil loss. Soil Sci. Soc. Amer. J. 68:935-942.

Lal, R. 1993. Soil erosion and conservation in West Africa, p. 7-25. In: Pimentel, R. (ed.). World soil erosion and conservation. Cambridge University Press, Cambridge, UK.

Lal, R. and J.M. Kimble. 2001. Importance of soil bulk density and methods of its measurement, p. 31-44. In: Lal, R., J.M. Kimble, R.F. Follett, and B.A. Stewart (eds.). Assessment methods for soil carbon, CRC Press LLC, Boca Raton, FL.

Le Bissonnais, Y. 1996. Aggregate stability and assessment of soil crustability and erodability: I. Theory and methodology. Eur. J. Soil Sci. 47:425-437.

Le Bissonnais, Y. and D. Arrouays. 1997. Aggregate stability and assessment of soil crustability and erodibility: II. Application to humic loamy soils with various organic carbon contents. Eur. J. Soil Sci. 48:39-48.

Lee, K.E. and R.C. Foster. 1991. Soil fauna and soil structure. Austral. J. Soil Res. 29:745-775.

Loveland, P. and J. Webb. 2003. Is there a critical level of organic matter in the agricultural soils of the temperate regions: A review. Soil Tillage Res. 70:1-18.

Mays, N. 2013. Groundcover management system and nutrient source impact physical soil quality indicators in an organically managed apple orchard. MS thesis, Univ. Ark., Fayetteville, AR.

Mays, N., K.R. Brye, C. R. Rom, M. Savin, and M.E. Garcia. 2014. Groundcover management and nutrient source effects on soil carbon and nitrogen sequestration in an organically managed apple orchard in the Ozark Highlands. HortScience 49:637-644.

Merwin, I.A., J.A. Ray, and P.D. Curtis. 1999. Orchard groundcover management systems affect meadow vole populations and damage to apple trees. HortScience 34:271-274. 
Merwin, I.A., D.A. Rosenberger, C.A. Engle, D.L. Rist, and M. Fargione. 1995. Comparing mulches, herbicides, and cultivation as orchard groundcover management systems. HortTechnology 5:151-158.

Merwin, I.A., W.C. Stiles, and H.M. van Es. 1994. Orchard groundcover management impacts on soil physical properties. J. Amer. Soc. Hort. Sci. 119:216-222.

Motschenbacher, J.M. 2012. Long-term effects of rice rotation, tillage, and fertility on nearsurface soil carbon and nitrogen cycling. $\mathrm{PhD}$ diss., Univ. Arkansas, Fayetteville, AR.

Mulumba, L.N. and R. Lal. 2007. Mulching effects on selected soil physical properties. Soil Tillage Res. 98:106-111.

Peck, G.M., I.A. Merwin, J.E. Thies, R.R. Schindelbeck, and M.G. Brown. 2011. Soil properties change during the transition to integrated and organic apple production in a New York orchard. Appl. Soil Ecol. 48:18-30.

Reganold, J.P., J.D. Glover, P.K. Andrews, and H.R. Hinman. 2001. Sustainability of three apple production systems. Nature 410:926930.

Reynolds, W.D., D.E. Elrick, and E.G. Youngs. 2002. Single-ring and double or concentricring infiltrometers, p. 821-826. In: Dane, J.H. and G.C. Topp (eds.). Methods of soil analysis: Part 4, physical methods. SSSA, Madison, WI.

Rom, C.R., M.E. Garcia, J. McAfee, H. Friedrich, H.S. Choi, D.T. Johnson, J. Popp, and M. Savin. 2010. The effects of groundcover management and nutrient source during organic orchard establishment. In: Prange, R.K. and S.D. Bishop (eds.). Proc. Organic Fruit Conference. Acta Hort 873, ISHS 2010.

Sanchez, J.E., C.E. Edson, G.W. Bird, M.E. Whalon, T.C. Wilson, R.R. Harwood, K. Kizilkaya, J.E Nugent, W. Klein, A. Middleton, T.L. Loudon, D.R. Mutch, and J. Scrimger. 2003. Orchard floor and nitrogen management influences soil and water quality and tart cherry yields. J. Amer. Soc. Hort. Sci. 128:277-284.

Saxton, K.E. and W.J. Rawls. 2005. Soil water characteristic estimates by texture and organic matter for hydrologic solutions. Soil Sci. Soc. Amer. J. 70:1569-1578.

Six, J., H. Bossuyt, S. Degryze, and K. Denef 2004. A history of research on the link between (micro)aggregates, soil biota, and soil organic matter dynamics. Soil Tillage Res. 79:7-31.

Smith, S.F. 2013. Long-term residue and water management effects on soil respiration and soil aggregate stability in a wheat-soybean, doublecrop system in eastern Arkansas. MS thesis, Univ. Arkansas, Fayetteville, AR.

Soane, B.D. 1990. The role of organic matter in soil compactibility: A review of some practical aspects. Soil Tillage Res. 16:179-201.

Stern, R., M. Ben-Hur, and I. Shainberg. 1991. Clay mineralogy effect of rain infiltration, seal formation, and soil losses. Soil Sci. 152:455462.

Stock, O. and N.K. Downes. 2008. Effects of additions of organic matter on the penetration resistance of glacial till for the entire water tension range. Soil Tillage Res. 99:191-201.
Tisdall, J.M. and J.M. Oades. 1982. Organic matter and water-stable aggregates in soils. J. Soil Sci. 33:141-163.

U.S. Department of Agriculture. 1969. Soil survey, Washington County, AR. US Government Printing Office, Washington, DC.

U.S. Department of Agriculture, Agricultural Marketing Service. 2012. Organic regulations. 22 Aug. 2012. <http://www.ams.usda.gov/ AMSv1.0/nop>.

University of Arkansas Cooperative Extension Service. 2013a. Arkansas plant disease control products guide. Misc. Publ. 154. 20 Apr. 2013. $<$ http://www.uaex.edu/Other_Areas/publications/ PDF/MP154/MP154.pdf>.

University of Arkansas Cooperative Extension Service. 2013b. Insecticide recommendations for Arkansas. Misc. Publ. 144. 20 Apr. 2013. <http:// www.uaex.edu/Other_Areas/publications/ PDF/MP144/MP144.pdf>.

van Rhee, J.A. 1977. Effects of soil pollution on earthworms. Pedobiologia (Jena) 17:201-208.

Wakindiki, I.I.C. and M. Ben-Hur. 2002. Soil mineralogy and texture effects on crust micromorphology, infiltration, and erosion. Soil Sci. Soc. Amer. J. 66:897-905.

Wells, M.L. 2011. Response of pecan orchard soil chemical and biological quality indicators to poultry litter application and clover cover crops. HortScience 46:306-310.

Yoder, R.E. 1936. A direct method of aggregate analysis of soils and a study of the physical nature of erosion losses. J. Amer. Soc. Agron. 28:337-351. 